\title{
Tumor-suppressive microRNA-206 as a dual inhibitor of $M E T$ and EGFR oncogenic signaling in lung squamous cell carcinoma
}

\author{
HIROKO MATAKI $^{1}$, NAOHIKO SEKI ${ }^{3}$, TAKESHI CHIYOMARU ${ }^{2}$, HIDEKI ENOKIDA $^{2}$, \\ YUSUKE GOTO $^{3}$, TOMOHIRO KUMAMOTO ${ }^{1}$, KENTARO MACHIDA ${ }^{1}$, \\ KEIKO MIZUNO ${ }^{1}$, MASAYUKI NAKAGAWA ${ }^{2}$ and HIROMASA INOUE ${ }^{1}$ \\ Departments of ${ }^{1}$ Pulmonary Medicine and ${ }^{2}$ Urology, Graduate School of Medical and Dental Sciences, Kagoshima University, \\ Kagoshima; ${ }^{3}$ Department of Functional Genomics, Chiba University Graduate School of Medicine, Chiba, Japan
}

Received September 13, 2014; Accepted October 27, 2014

DOI: $10.3892 / \mathrm{ijo} .2014 .2802$

\begin{abstract}
Expression of the oncogene hepatocyte growth factor receptor (MET) and phosphorylation of the MET protein have been associated with both primary and acquired resistance to tyrosine kinase inhibitors (TKIs) used in therapy targeting the epidermal growth factor receptor (EGFR) in patients with non-small cell lung cancers (NSCLCs). Therefore, simultaneous inhibition of both of these receptor tyrosine kinases (RTKs) should improve disease treatment. Our previous study of microRNA (miRNA) expression signatures of lung squamous cell carcinoma (lung-SCC) revealed that microRNA-206 $(m i R-206)$ was significantly reduced in lung-SCC tissues, suggesting that $m i R-206$ functions as a tumor suppressor in the disease. Furthermore, putative miR-206 binding sites were annotated in the 3'-UTRs of MET and EGFR RTKs in miRNA databases. The aim of the study was to investigate the functional significance of $m i R-206$ in lung-SCC and to confirm the inhibition of both MET and EGFR oncogenic signaling by expression of $m i R-206$ in cancer cells. We found that restoration of mature miR-206 inhibited cancer cell proliferation, migration, and invasion in EBC-1 cells through downregulation of both mRNA and protein levels of MET and EGFR. Interestingly, phosphorylation of ERK1/2 and AKT signaling were inhibited by restoration of $m i R-206$ in cancer cells. Overexpression of MET and EGFR were observed in clinical specimens of lung-SCC. Tumor-suppressive $m i R-206$ inhibited dual signaling networks activated by MET and EGFR, and these findings will provide new insights into the novel molecular mechanisms of lung-SCC oncogenesis and new therapeutic approaches for the treatment of this disease.
\end{abstract}

Correspondence to: Dr Hiromasa Inoue, Department of Pulmonary Medicine, Graduate School of Medical and Dental Sciences, Kagoshima University, 8-35-1 Sakuragaoka, Kagoshima 890-8520, Japan E-mail: inoue-pulm@umin.net

Key words: lung squamous cell carcinoma, microRNA, miR-206, tumor suppressor, receptor tyrosine kinase, EGFR, MET

\section{Introduction}

Lung cancer remains the most frequent cause of cancerrelated death in developed countries (1). Approximately $80 \%$ of lung cancers are classified histopathologically as non-small cell lung cancers (NSCLC). NSCLCs are subdivided into four major histological subtypes with distinct pathological characteristics: adenocarcinoma, squamous cell carcinoma, large cell carcinoma and neuroendocrine cancer (2). Patients with NSCLCs in advanced stages rarely survive more than five years despite aggressive chemotherapy, molecularlytargeted therapy or chemoradiotherapy (3).

Altered expression of cell surface growth factor receptors, including the RTK family, has frequently been observed in many types of human cancer $(4,5)$. Recently, new targeted therapeutics have been developed to inhibit oncogenic receptors-mediated signaling, including that in NSCLCs (3). In NSCLCs, epidermal growth factor receptor (EGFR) and the RTK for hepatocyte growth factors (MET) are activated. Signaling by EGFR and MET leads to NSCLC cell proliferation and promotes survival and invasion (6,7). It has been shown that MET expression and phosphorylation are associated with both primary and acquired resistance to tyrosine kinase inhibitor (TKI) based therapy in patients with NSCLCs, such as EGFR (8-10). Thus, targeting MET would be an important approach to overcoming resistance to TKIs in lung cancer.

The discovery of non-coding RNAs (ncRNAs) in the human genome was an important conceptual breakthrough in the post-genome sequencing era (11). Improved understanding of ncRNAs is necessary for continued progress in cancer research. microRNAs (miRNAs) repress gene expression by inhibiting mRNA translation or by promoting mRNA degradation. Aberrant expression of miRNAs significantly contributes to cancer development, metastasis and drug resistance (12-14). Currently, 2,578 human mature miRNAs are registered at miRBase release 20.0 (http://microrna.sanger. ac.uk/). miRNAs are unique in their ability to regulate multiple protein-coding genes. Bioinformatic predictions indicate that miRNAs regulate approximately $30-60 \%$ (or more) of the protein-coding genes in the human genome $(15,16)$.

Previously, our miRNA expression signature of lung squamous cell carcinoma (lung-SCC) revealed that microRNA-206 (miR-206) was significantly reduced in cancer tissues (17), 
suggesting that this miRNA functions as a tumor suppressor in lung-SCC. Interestingly, MET and EGFR genes have putative $m i R-206$ binding sites in their 3'-UTRs as determined by miRNA databases. The aim of this study was to investigate the functional significance of $m i R-206$ in lung-SCC cells and whether inhibition of RTKs (MET and EGFR) by miR-206 mediated oncogenic signaling in cancer cells.

\section{Materials and methods}

Clinical specimens and RNA extraction. A total of 32 lung-SCCs and 22 normal lung specimens were collected from patients who underwent pneumonectomy at Kagoshima University Hospital from 2010 to 2013. Archival formalin-fixed paraffin embedded (FFPE) samples were used for qRT-PCR analysis and immunohistochemistry.

Samples were staged according to the International Association for the Study of Lung Cancer TNM classification, and they were histologically graded (18). Our study was approved by the Institutional Review Board for Clinical Research of Kagoshima University School of Medicine. Prior written informed consent and approval were provided by each patient.

FFPE tissues were sectioned to a thickness of $10 \mu \mathrm{m}$ and 8 tissue sections were used for RNA extraction. Total RNA (including miRNA) was extracted using Recover All ${ }^{\mathrm{TM}}$ Total Nucleic Acid Isolation kit (Ambion, Austin, TX, USA) using the manufacturer's protocols. The integrity of the RNA was checked with an RNA 6000 Nano Assay kit and a 2100 Bioanalyzer (Agilent Technologies, Santa Clara, CA, USA).

Cell culture. We used a human lung-SCC cell line (EBC-1) obtained from Japanese Cancer Research Resources Bank (JCRB). Cells were grown in RPMI-1640 medium supplemented with $10 \%$ fetal bovine serum and maintained in a humidified incubator $\left(5 \% \mathrm{CO}_{2}\right)$ at $37^{\circ} \mathrm{C}$.

Quantitative real-time PCR ( $q R T-P C R)$. The procedure for PCR quantification was as described previously (19-21). TaqMan probes and primers for MET (P/N: Hs01565584_m1, Applied Biosystems, Foster City, CA, USA) and EGFR (P/N: Hs01076078_m1, Applied Biosystems) were assayon-demand gene expression products. Stem-loop RT-PCR for $m i R-206$ (P/N: 000510, Applied Biosystems) was used to quantify the expression levels of miRNAs according to the manufacturer's protocol. To normalize the data for quantification of MET mRNA and miRNAs, we used human GUSB (P/N: Hs99999908_m1; Applied Biosystems) and RNU48 (P/N: 001006; Applied Biosystems), respectively, and the $\Delta \Delta \mathrm{Ct}$ method was employed to calculate the fold-change.

Transfections with mature miRNA into EBC-1 cells. The following mature miRNA species were used in the present study: Pre-miR ${ }^{\mathrm{TM}}$ miRNA precursors (hsa-miR-206; P/N: AM 17100 and negative control miRNA; P/N: AM 17111). RNAs were incubated with Opti-MEM (Invitrogen, Carlsbad, CA, USA) and Lipofectamine RNAiMax reagent (Invitrogen) as described (19-21).

Cell proliferation, migration and invasion assays. Cells were transfected with $10 \mathrm{nM}$ miRNAs by reverse transfection and plated in 96-well plates at $3 \times 10^{3}$ cells per well. After $72 \mathrm{~h}$, cell proliferation was determined with the XTT assay using the Cell Proliferation Kit II (Roche Molecular Biochemicals, Mannheim, Germany) as described (19-21).

Cell migration activity was evaluated with wound healing assays. Cells were plated in 6 -well plates at $8 \times 10^{5}$ cells per well, and after $48 \mathrm{~h}$ of transfection, the cell monolayer was scraped using a P-20 micropipette tip. The initial gap length $(0 \mathrm{~h})$ and the residual gap length $48 \mathrm{~h}$ after wounding were calculated from photomicrographs as described (19-21).

Cell invasion assays were performed using modified Boyden chambers, consisting of Transwell-precoated Matrigel membrane filter inserts with $8-\mu$ m pores in 24 -well tissue culture plates (BD Biosciences, Bedford, MA, USA). After $72 \mathrm{~h}$ of transfection, cells were plated in 24-well plates at $1 \times 10^{5}$ cells per well. Minimum essential medium containing $10 \%$ fetal bovine serum in the lower chamber served as the chemoattractant as described previously (19-21). All experiments were performed in triplicate.

Flow cytometry. EBC-1 cells were transiently transfected with miRNAs and were harvested $72 \mathrm{~h}$ later by trypsinisation. The analysis of apoptosis was done as previously described (22). Cells for cell cycle analysis were stained with PI using the CycleTest ${ }^{\mathrm{TM}}$ Plus DNA Reagent kit (BD Biosciences) following their protocol and analyzed with a FACScan (BD Biosciences). The percentage of the cells in the G0/G1, S and G2/M phase were counted and compared. Experiments were done in triplicate.

Western blotting. After a 72-h period of transfection, protein lysates ( $1 \mu \mathrm{g}$ for MET and $20 \mu \mathrm{g}$ for others) were separated on NuPAGE on 4-12\% Bis-Tris gels (Invitrogen) and transferred to polyvinylidene fluoride membranes. Immunoblotting was done with the following diluted $(1: 1,000)$ antibodies from Cell Signaling, Danvers, MA, USA: polyclonal anti-EGFR antibody (\#4267), anti-p-EGFR (Tyr1045) antibody (\#2237), anti-p-EGFR (Tyr1068) antibody (\#3777), anti-MET antibody (\#8198), anti-p-MET (Tyr1234/1235) antibody (\#3077), antip-MET (Tyr1003) antibody (\#3135), anti-p-MET (Tyr1349) antibody (\#3133), anti-p44/42 MAPK (Erk1/2) antibody (\#4965), anti-p-Erk1/2 antibody (\#4370), anti-Akt (pan) antibody (\#4691), anti-p-Akt antibody (\#4060). Anti-GAPDH antibody (MAB374) was from Chemicon, Temecula, CA, USA. The membrane was washed and then incubated with anti-rabbit-IgG, HRP-linked antibody (\#7074; Cell Signaling). Specific complexes were visualized with an echochemiluminescence (ECL) detection system (GE Healthcare, Little Chalfont, UK) as described previously (19-22).

Plasmid construction and dual-luciferase reporter assay. Partial wild-type sequence of the MET 3'-UTR or those with a mutant miR-206 target site (position 499-505 or position 814-820 of the MET 3'-UTR) were inserted between the XhoI-PmeI restriction sites in the 3'-UTR of the hRluc gene in the psiCHECK-2 vector (C8021; Promega, Madison, WI, USA). Similarly, partial wild-type sequences of the EGFR 3'-UTR or those with a mutant miR-206 target site (position 746-752 of the EGFR 3'UTR) were inserted into the vector.

The synthesized DNA was cloned into the psiCHECK-2 vector. EBC-1 cells were transfected with 20 or $50 \mathrm{ng}$ vector, 
$10 \mathrm{nM}$ miRNAs and $1 \mu 1$ Lipofectamine 2000 (Invitrogen) in $100 \mu 1$ Opti-MEM (Invitrogen). The activities of firefly and Renilla luciferases in cell lysates were determined with a dualluciferase assay system (E1910; Promega). Normalized data were calculated as the quotient of Renilla/firefly luciferase activities.

Immunohistochemistry. FFPE tissues were sectioned to a thickness of $5 \mu \mathrm{m}$ and 2 tissue sections were used for immunohistochemistry. The tissues were immunostained following the manufacturer's protocol with an UltraVision Detection system (Thermo Scientific). The primary rabbit polyclonal antibodies against MET (\#8198; Cell Signaling) and EGFR (\#4267; Cell Signaling) were diluted 1:300 and 1:200, respectively. The slides were treated with biotinylated goat anti-rabbit antibodies. Diaminobenzidine hydrogen peroxidase was the chromogen and counterstaining was done with $0.5 \%$ hematoxylin. For immunohistochemical analyses, we followed a previous report (23). Briefly, a proportional cut-off of $\geq 50 \%$ was selected to ensure that a majority of the cells within a given specimen expressed MET/EGFR at either a weak (+), moderate $(++)$, or strong $(+++)$ intensity level. Specimens with no or equivocal staining in tumor cells or $<50 \%$ of tumor cells staining at any given intensity were considered negative (-). NSCLC tumors expressing moderate or strong levels of MET/ EGFR in $\geq 50 \%$ of cells ( ++ or +++ ) were classified as MET/ EGFR-positive. Otherwise, they were classified as negative. Two observers (Hiroko Mataki and Takeshi Chiyomaru) evaluated the slides simultaneously, and both were blinded to clinical data. We recorded the mean of the values determined by the two observers. Interobserver differences were $<5 \%$.

Identification of putative miR-206 target genes. To identify putative $m i R$-206-regulated genes, we used the TargetScan database (http://www.targetscan.org/). Candidate $m i R-206$ target genes were analyzed in Kyoto Encyclopedia of Genes and Genomics (KEGG) pathway categories using the GeneCodis program. Finally, we investigated the expression status of putative targets of $m i R-206$ using lung-SCC clinical expression data from GEO database (accession no. GSE 11117). Our strategies of identification of putative tumor-suppressive miRNAs target genes were described in previous studies (19-22).

Statistical analysis. Relationships between two or three variables and numerical values were analyzed using the Mann-Whitney $U$ test or Bonferroni-adjusted Mann-Whitney $U$ test. Spearman's rank test was used to evaluate the correlation between the expressions of $m i R-206$ and $m i R-133 b$. Expert StatView version 4 was used in these analyses.

\section{Results}

Expression levels of miR-206 in lung-SCC clinical specimens. To validate our past miRNA signature of lung-SCC, we evaluated the expression of miR-206 in lung-SCC tissues $(\mathrm{n}=32)$ and normal lung tissues $(n=22)$. The patient backgrounds and clinicopathological characteristics are summarized in Table I. The typical FFPE specimens that were used for RNA extraction and expression analysis in this study are shown in Fig. 1.
Table I. Characteristics of the patients.

A, Lung cancer

\begin{tabular}{lcr}
\hline Lung cancer & $\mathrm{n}$ & $(\%)$ \\
\hline Total number & 32 & \\
Median age (range) & $71(50-88)$ & \\
Gender & & \\
Male & 30 & $(93.7)$ \\
Female & 2 & $(6.3)$ \\
Pathological tumor stage & & \\
$\mathrm{I}_{\mathrm{A}}$ & 4 & $(12.5)$ \\
$\mathrm{I}_{\mathrm{B}}$ & 8 & $(25.0)$ \\
$\mathrm{II}_{\mathrm{A}}$ & 4 & $(12.5)$ \\
$\mathrm{II}_{\mathrm{B}}$ & 5 & $(25.0)$ \\
III $_{\mathrm{A}}$ & 8 & $(3.1)$ \\
III $_{\mathrm{B}}$ & 1 & $(6.3)$ \\
Unknown $_{\text {Differentiation }}$ & 2 & \\
Well $_{\text {Moderately }}$ & & $(25.0)$ \\
Poorly & 8 & $(59.4)$ \\
Unknown & 19 & $(6.3)$ \\
Pleural invasion & 3 &
\end{tabular}

Pleural invasion

$\begin{array}{ll}(+) & 15 \\ (-) & 17\end{array}$

Venous invasion

(+) 16

Lymphatic invasion

(+) 16

$(-)$

Recurrence

(+) 9

(-) 20

Unknown

Immunohistochemistry

MET

$\begin{array}{ll}(+) & 1 \\ (++) & 2 \\ (+++) & 0 \\ \text { EGFR } & \end{array}$

$\begin{array}{ll}(+) & 1 \\ (++) & 2 \\ (++++) & 2\end{array}$

B, Normal lung

\begin{tabular}{lc}
\hline Normal lung & $\mathrm{n}$ \\
\hline Total number & 22 \\
Median age (range) & $71(50-88)$ \\
Gender & \\
Male & 22 \\
Female & 0
\end{tabular}




\section{A Cancer}
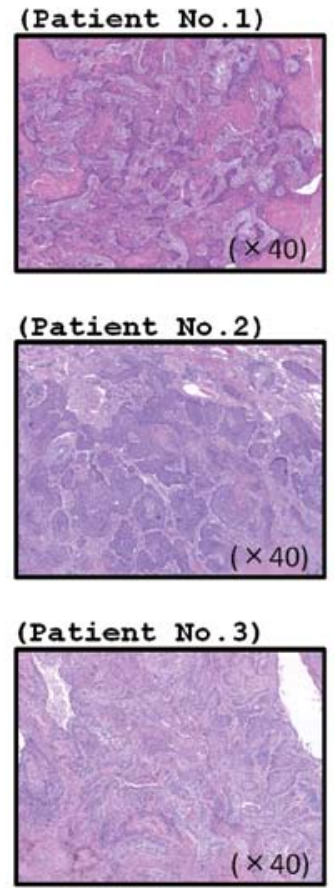
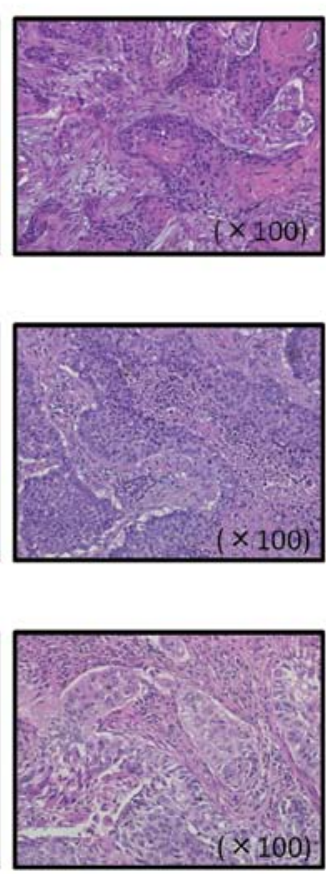

B Normal lung
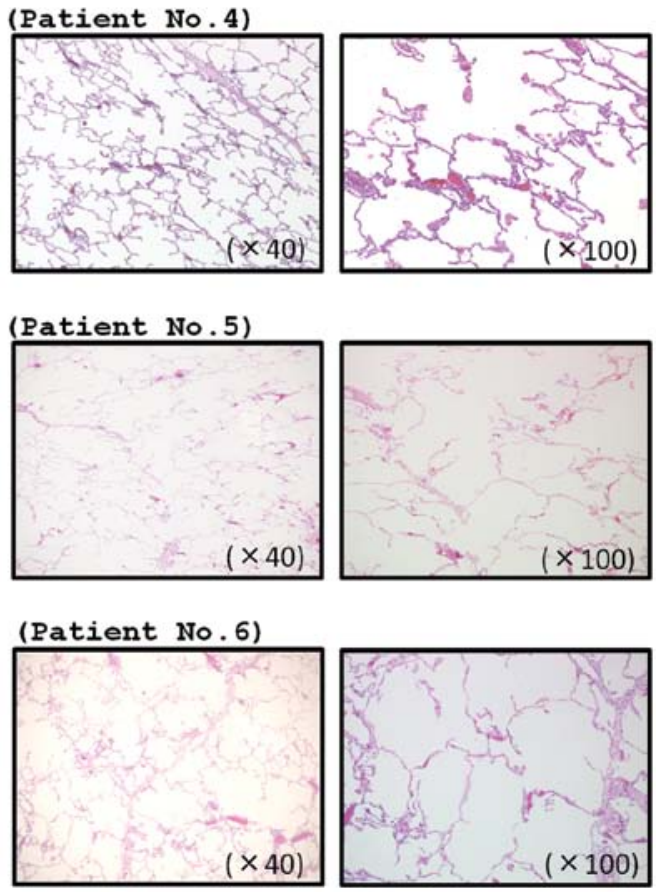

Figure 1. Hematoxylin-eosin staining of FFPE specimens. (A) Typical specimens of lung-SCC. (B) Normal lung tissues. Left panels, original magnification, $\mathrm{x} 40$; right panels, original magnification, $\mathrm{x} 100$.

A

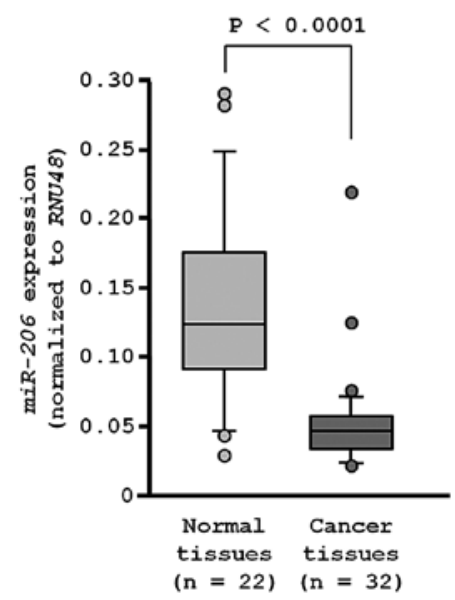

B

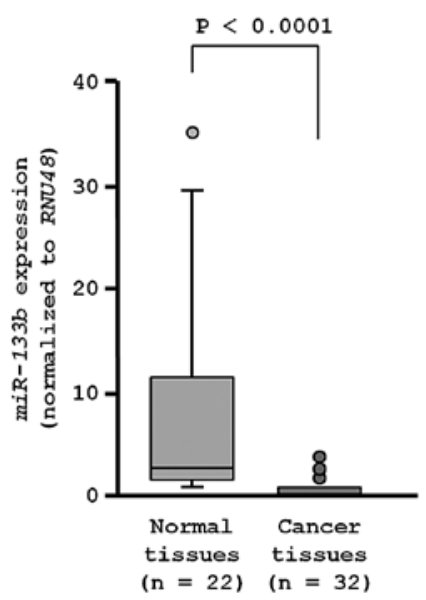

C

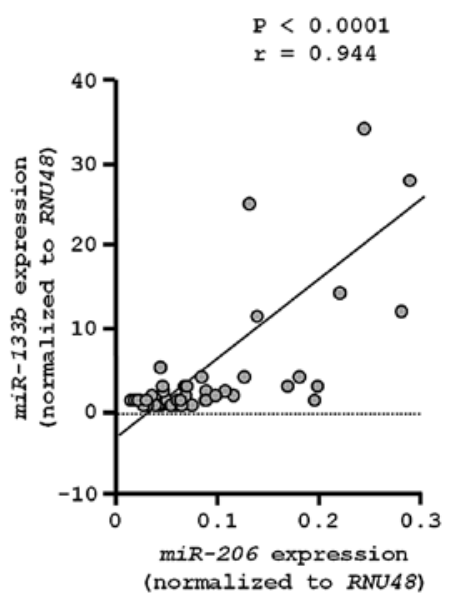

Figure 2. The expression levels of $m i R-206$ and $m i R-133 b$ in clinical specimens. (A) The expression levels of $m i R-206$ in clinical specimens. (B) The expression levels of $m i R-133 b$ in clinical specimens. (A and B) Real-time PCR showed that the expression levels of $m i R-206$ and $m i R-133 b$ was significantly lower in lung-SCC tissues than in normal lung tissues. RNU48 was used as an internal control. (C) Positive correlation between the expression of miR-206 and that of $m i R-133 b$. Spearman's rank test showed a positive correlation between the expression of $m i R-206$ and that of $m i R-133 b(\mathrm{r}=0.944$ and $\mathrm{P}<0.0001)$.

The expression levels of $m i R$-206 were significantly reduced in tumor tissues compared to corresponding non-cancer tissues ( $\mathrm{P}<0.0001 ;$ Fig. 2A). In the human genome, $m i R-206$ and miR-133b are located close together on chromosome $6 \mathrm{p} 12.1$ and constitute clustered miRNAs. Thus, we also investigated the expression levels of $m i R-133 b$ in lung-SCC tissues. The $m i R-133 b$ expression levels were significantly reduced in cancer tissues (Fig. 2B). Spearman's rank test showed a positive correlation between the expression of $m i R-206$ and that of $m i R-133 b$ ( $\mathrm{r}=0.944$ and $\mathrm{P}<0.0001$, Fig. 2C).
There was no significant relationship between the expression of miRNAs and other clinicopathological parameters (stage, grade, infiltration).

Effects of miR-206 restoration on the proliferation, induction of apoptosis and cell cycle arrest of EBC-1 cells. To examine the functional roles of $m i R-206$, we performed gain-of-function studies using miRNA transfection into EBC-1 cells.

XTT assays revealed significant inhibition of cell proliferation in EBC-1 cells transfected with miR-206 in comparison 

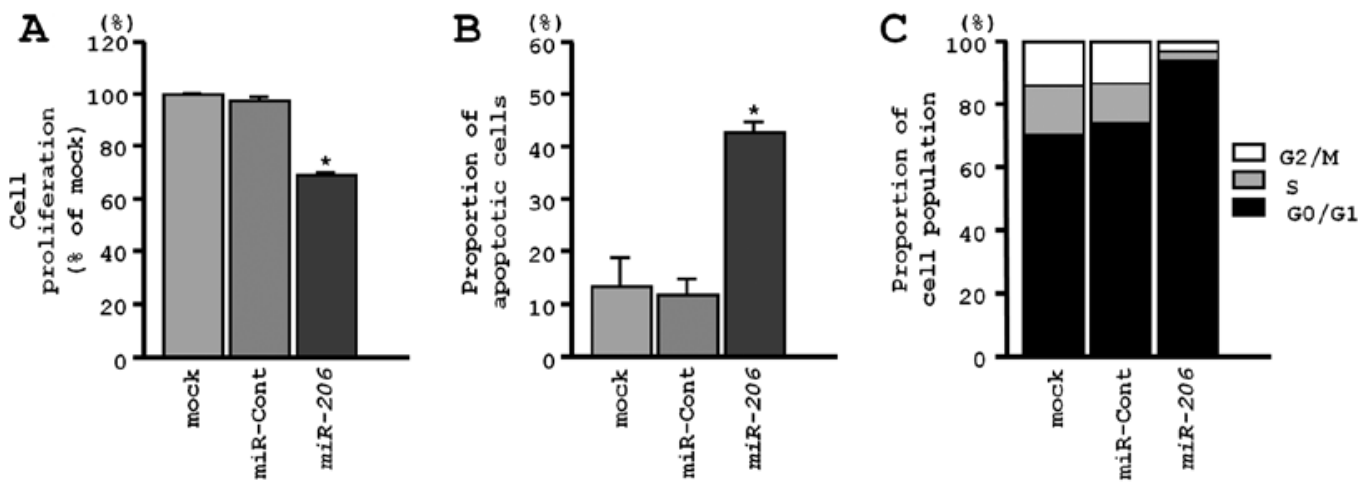

Figure 3. Effects of $m i R-206$ transfection on EBC-1 cells. (A) Cell proliferation was determined with XTT assays $72 \mathrm{~h}$ after transfection with $10 \mathrm{nM} m i R$-206, miR-control or mock transfection. (B) Assessment of apoptosis in EBC-1 cells. Data show induction of apoptosis following restoration of $m i R$-206. (C) Cell cycle assay showing induction of G0/G1 cell arrest by $m i R-206$ expression. ${ }^{*} \mathrm{P}<0.001$.

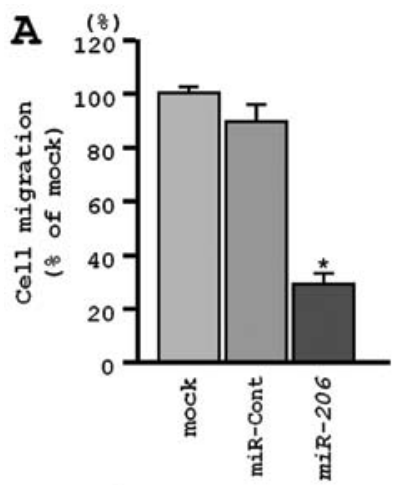

mock
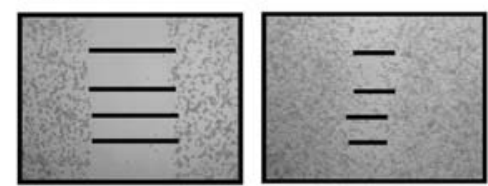

miR-control

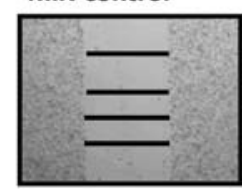

miR-206

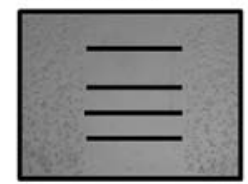

$0 \mathrm{~h}$
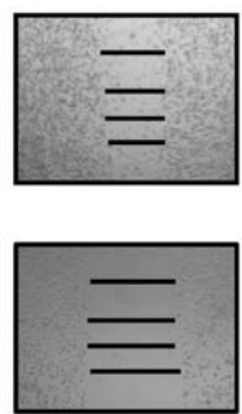

$48 \mathrm{~h}$
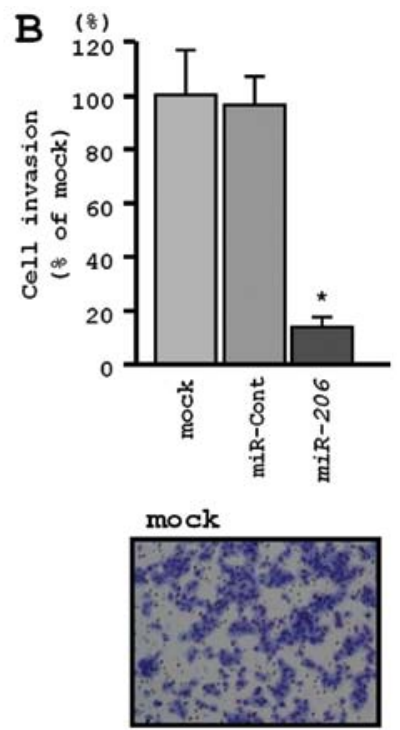

miR-control

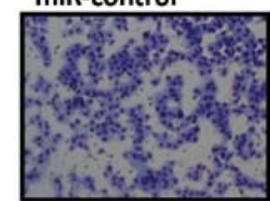

$\operatorname{miR}-206$

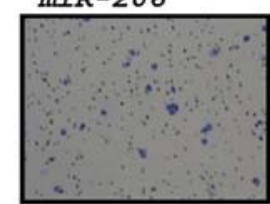

Figure 4. Restoration of miR-206 affected cell migration and invasion in EBC-1 cells. (A) Cell migration activity was determined by migration assay $48 \mathrm{~h}$ after transfection with miR-206 and mock or miR-control. (B) Cell invasion activity was determined by Matrigel invasion assay $48 \mathrm{~h}$ after transfection. ${ }^{*} \mathrm{P}<0.0001$.

with mock-transfected cells and control transfectants $(\mathrm{P}<0.0001$, Fig. 3A). Because $m i R-206$ restoration significantly inhibited cell proliferation in a lung-SCC cell line, we hypothesized that miR-206 expression may induce apoptosis or cell cycle arrest. Using flow cytometry, we investigated the number of apoptotic cells following restoration of $m i R-206$ expression. The apoptotic and early apoptotic fractions were greater in miR-206 transfectants than in the mock transfectants or the control (Fig. 3B). In terms of the cell cycle distribution, the number of cells in the G0/1 phase was significantly greater in miR-206 transfectants than in mock or miR-control transfectants (Fig. 3C).

Effects of miR-206 restoration on migration and invasion activities of EBC-1 cells. Wound healing assays revealed significant inhibition of EBC-1 cell migration after transfection with miR-206 ( $\mathrm{P}<0.0001$, respectively; Fig. 4A). Similarly, Matrigel invasion assays revealed that transfection with 


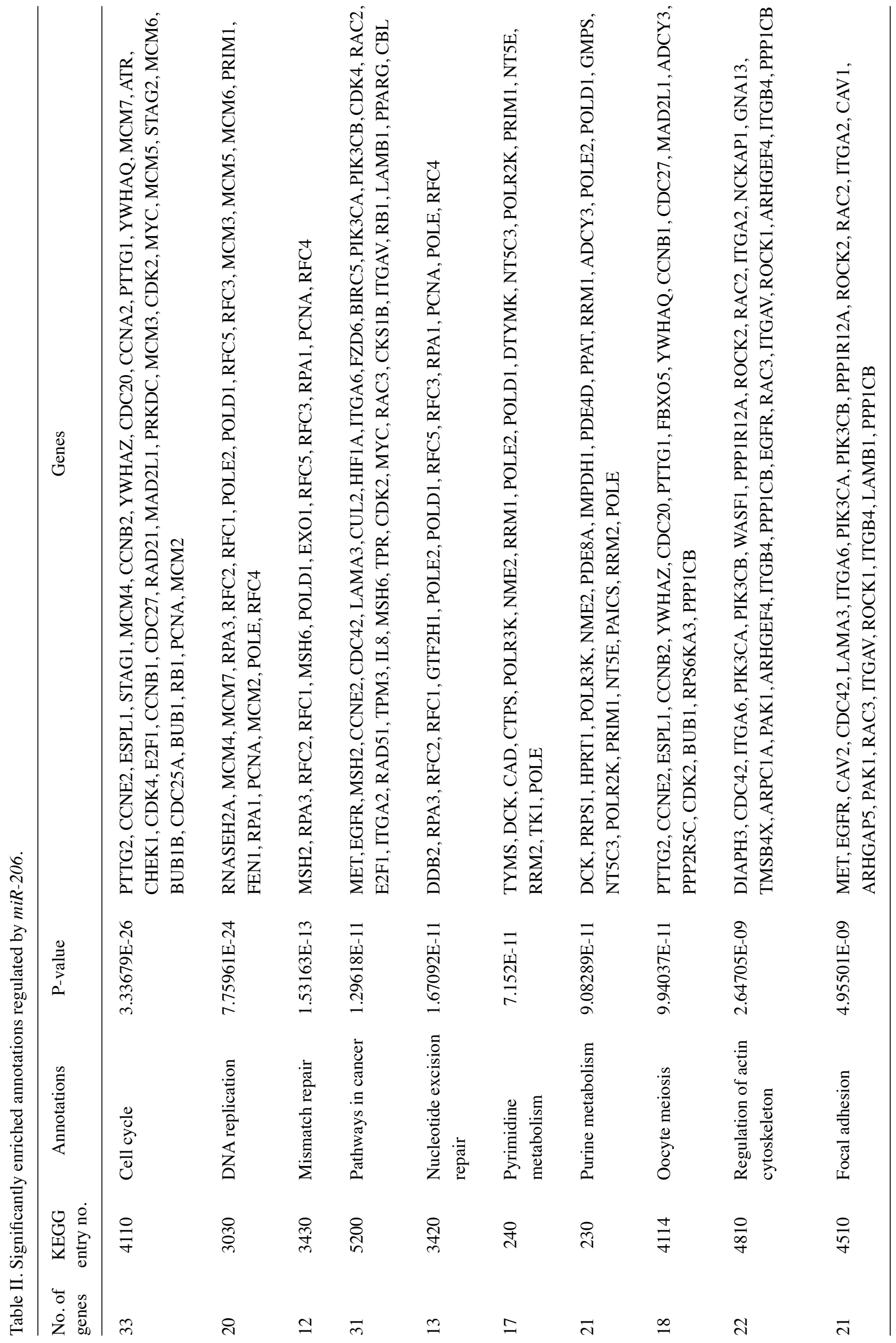


A

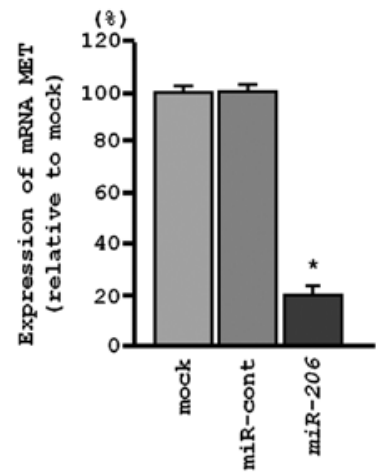

C

Position $499-505$ of MET 3'UTR
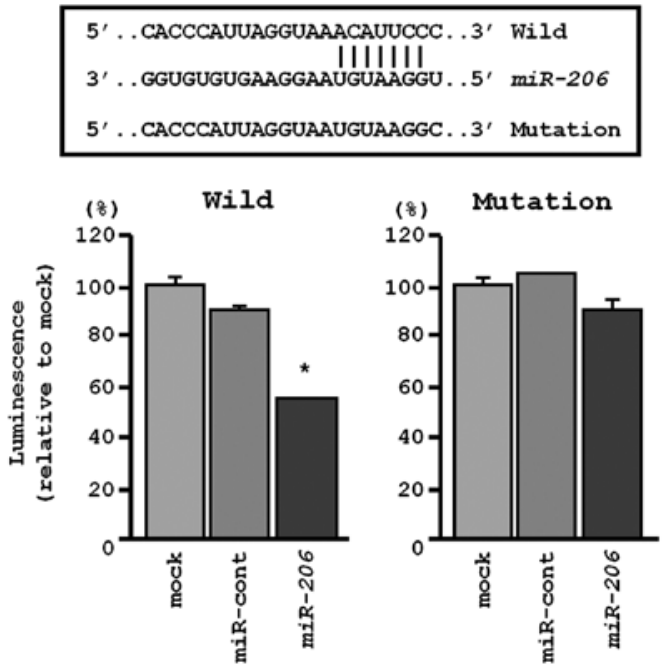

B

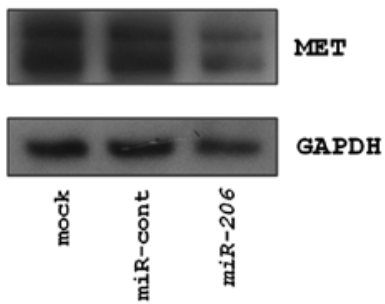

Position 814-820 of MET $3^{\prime}$ UTR
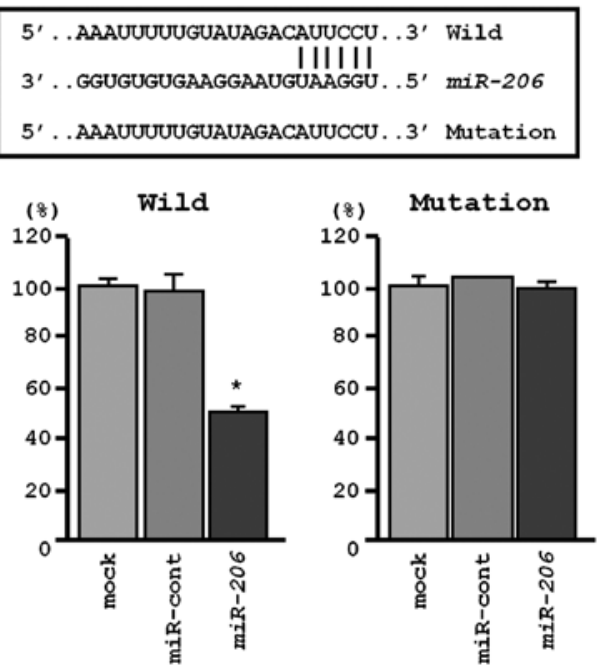

Figure 5. Direct regulation of MET by $m i R-206$ in EBC-1 cells. (A) MET mRNA expression was evaluated by qRT-PCR $72 \mathrm{~h}$ after transfection with $m i R-206$. GUSB was used as an internal control. (B) MET protein expression was evaluated by western blotting $72 \mathrm{~h}$ after transfection with $m i R-206$. GAPDH was used as a loading control. (C) Putative miR-206 binding sites in the 3'-UTR of MET mRNA. Luciferase reporter assay using vectors encoding putative miR-206 target sites at positions 499-505 and 814-820 for both wild-types and mutation-types. Renilla luciferase values were normalized to firefly luciferase values. ${ }^{*} \mathrm{P}<0.0001$.

miR-206 reduced cell invasion. Indeed, the number of invading cells was significantly decreased in EBC-1 cells transfected with miR-206 (P<0.0001) (Fig. 4B).

Identification of candidate genes targeted by miR-206 in lung-SCC. To identify molecular targets of $m i R-206$, we used combination of in silico analysis and lung-SCC gene expression data from GEO (accession no. GSE 11117) as described in our previous studies (19-22). A total of 3,117 genes were putative targets of $m i R-206$ according to the TargetScan database. Among those 3,117 genes, 836 were upregulated in lung-SCC clinical specimens according to GEO database. The 836 genes were categorized to known pathways according to KEGG and top 10 pathways and involved genes are shown in Table II.

Because RTKs contribute to cancer progression and metastasis, we focused on RTKs that contained $m i R-206$ binding sites in their 3'-UTRs and are upregulated in lung-SCC clinical specimens. We found that two RTK genes (MET and EGFR) were involved in 'pathways in cancer' and 'focal adhesion' pathways. Therefore, we focused on these two genes for further studies.

MET and EGFR were directly regulated by miR-206 in EBC-1 cells. We performed qRT-PCR and western blotting to confirm MET downregulation following restoration of $m i R-206$ expression in EBC-1. The mRNA and protein expression levels of MET and EGFR were significantly repressed in $m i R-206$ transfectants in comparison with mock or miR-control transfectants $(\mathrm{P}<0.001$, Figs. 5A and $\mathrm{B}$, and $6 \mathrm{~A}$ and $\mathrm{B})$.

The TargetScan database identified two putative target sites in the 3'-UTR of MET (Fig. 5C, upper). A luciferase reporter assay confirmed that the 3'-UTR of MET was indeed an actual target of $m i R-206$. Luciferase activity was significantly decreased in two miR-206 target sites (positions 499-505 and 814-820 in the 3'-UTR of MET) (Fig. 5C, lower).

Similarly, the TargetScan database identified one putative target site in the 3'-UTR of EGFR (Fig. 6C, upper). A luciferase reporter assay confirmed that the 3'-UTR of EGFR was the actual target of $m i R-206$. Specifically, the luciferase activity 


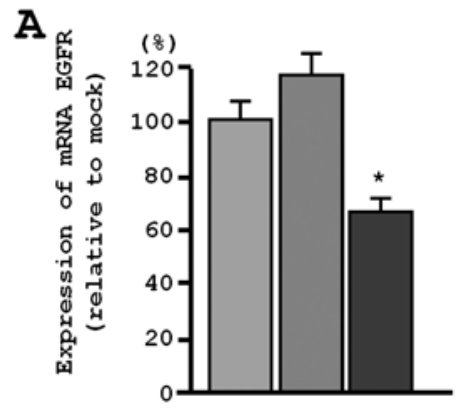

B

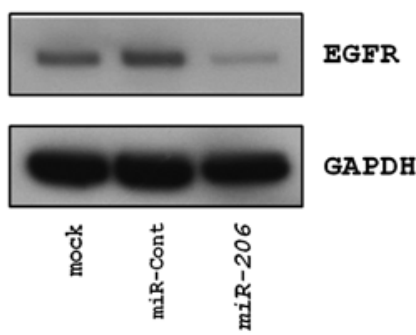

C

Position 746-752 of EGFR $3^{\prime}$ UTR

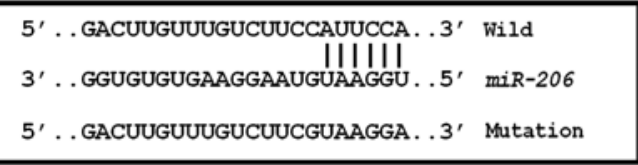

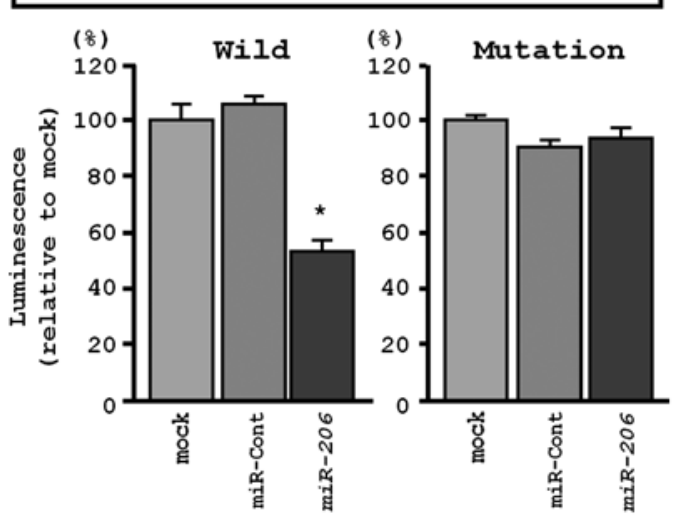

Figure 6. Direct regulation of EGFR by $m i R-206$ in EBC-1 cells. (A) EGFR mRNA expression was evaluated by qRT-PCR $72 \mathrm{~h}$ after transfection with $m i R-206$, mock or miR-control. GAPDH was used as an internal control. (B) EGFR protein expression was evaluated by western blotting $72 \mathrm{~h}$ after transfection. GAPDH was used as a loading control. (C) Putative miR-206 binding site in the 3'-UTR of EGFR mRNA (upper). Luciferase reporter assay using a vector encoding putative $m i R$-206 target site at positions 746-752 for both wild-type and mutant. Renilla luciferase values were normalized to firefly luciferase values. ${ }^{*} \mathrm{P}<0.0001$.

was significantly decreased at the $m i R$-206 target site (position 746-752 in the 3'-UTR of EGFR) (Fig. 6C, lower).

Restoration of miR-206 inhibited ERK and AKT signaling in $E B C-1$ cells. To investigate the effect of $m i R-206$ on pathway signaling, we checked the state of the phosphorylation of MET, EGFR and the downstream proteins of these RTKs (ERK and AKT) following $m i R$-206 expression.

As shown in Fig. 7, restoration of $m i R-206$ inhibited phosphorylation of MET (Tyr1003, Tyr1234/1239 and Tyr1349) and EGFR (Tyr1068 and Tyr1045) in EBC-1 cells. We also confirmed miR-206-mediated inhibition of phosphorylation of
ERK1/2 and AKT that are downstream from MET and EGFR (Fig. 7).

Expression of MET and EGFR in lung-SCC clinical specimens. We confirmed the expression status of MET and EGFR in lung-SCC clinical specimens using immunohistochemical staining. A total of 32 specimens were checked in this study, and two and four samples stained positively ( $\geq 50 \%$ of positive cells with moderate or strong staining) for MET and EGFR, respectively (Fig. 8). One sample stained positively for both MET and EGFR (Fig. 8). Clinicopathological characteristics are summarized in Table III

\section{Discussion}

Aberrant expression of miRNAs can disrupt tightly regulated RNA networks in normal cells, thereby promoting the development and progression of human cancers. The first step in defining the contribution of miRNAs to human cancers is to identify the miRNAs that are differentially expressed in cancer cells. Therefore, we have constructed miRNA expression signatures in various cancers, allowing us to identify tumorsuppressive miRNAs and their regulated cancer pathways $(22,24,25)$. Our lung-SCC signature revealed that $m i R-206$ was significantly reduced in cancer tissues (17).

The chromosomal location of $m i R-206$ in the human genome is of significant interest. $m i R-1-1 / m i R-133 a-2$, $m i R-1-2 / m i R-133 a-1$ and $m i R-206 / m i R-133 b$ form clusters in three different chromosomal regions, 20q13.33, 18q11.2 and $6 \mathrm{p} 12.1$, respectively. Our previous studies demonstrated that miR-1/133a clustered miRNAs function as tumor suppressors in various types of human cancers, targeting several oncogenes (26). The mature sequence of $m i R-206$ is similar to that of $m i R-1$ in terms of expression and function, but its sequence differs from that of $m i R-1$ by four nucleotides (26).

Our present data showed that restoration of $m i R-206$ significantly inhibited proliferation, migration and invasion in EBC-1 cells, suggesting that miR-206 functions as a tumor suppressor in lung-SCC. A tumor-suppressive function of $m i R-206$ has been reported in other types of cancers (27-31). These findings indicate that $m i R-206$ is closely involved in human cancer. We also found that expression of $m i R-133 b$ was reduced in lung-SCC tissues (Fig. 2B), and Spearman's rank test showed a positive correlation between the expression of $m i R-206$ and that of $m i R-133 b$ (Fig. 2C). It is likely that the $m i R-206 / m i R-133 b$ cluster is frequently reduced in cancer tissues and they function as tumor suppressors in lung-SCC. For patients with advanced lung-SCC, the standard therapeutic approach remains chemotherapy. Therefore, additional options to treat lung-SCC are needed. Elucidation of the molecular targets and pathways regulated by tumor suppressive $m i R-206$ or $m i R-133 b$ in lung-SCC enhances our understanding of the disease and suggests more effective strategies for future therapeutic interventions.

The next problem we pursued was the identification of the pathways/targets that were regulated by tumor-suppressive miR-206 in lung-SCC cells. We used a combination of expression data and in silico database analysis to identify tumor-suppressive $m i R$-206 regulated targets. In this screening, several putative pathways and targets were annotated to be 
Table III. Immunohistochemistry status and characteristics of the patients.

\begin{tabular}{|c|c|c|c|c|c|c|c|c|c|c|}
\hline \multirow[b]{2}{*}{$\begin{array}{l}\text { Patient } \\
\text { no. }\end{array}$} & \multirow[b]{2}{*}{$\begin{array}{l}\text { Pleural } \\
\text { invasion }\end{array}$} & \multirow[b]{2}{*}{$\begin{array}{l}\text { Venous } \\
\text { invasion }\end{array}$} & \multirow[b]{2}{*}{$\begin{array}{l}\text { Lymphatic } \\
\text { invasion }\end{array}$} & \multirow[b]{2}{*}{ Differentiation } & \multicolumn{3}{|c|}{$\begin{array}{c}\text { TNM } \\
\text { classification }\end{array}$} & \multirow[b]{2}{*}{$\begin{array}{l}\text { Pathological } \\
\text { tumor stage }\end{array}$} & \multicolumn{2}{|c|}{$\begin{array}{l}\text { Immunohisto- } \\
\text { chemistry }\end{array}$} \\
\hline & & & & & $\mathrm{T}$ & $\mathrm{N}$ & M & & MET & EGFR \\
\hline 1 & $(+++)$ & $(+)$ & $(+)$ & Moderately & 3 & 0 & 0 & $\mathrm{II}_{\mathrm{B}}$ & $(-)$ & $(-)$ \\
\hline 2 & $(-)$ & $(-)$ & $(-)$ & Well & 3 & 2 & 0 & $\mathrm{III}_{\mathrm{A}}$ & $(-)$ & $(-)$ \\
\hline 3 & $(-)$ & $(+)$ & $(+)$ & Moderately & $2 b$ & 2 & 0 & $\mathrm{III}_{\mathrm{A}}$ & $(-)$ & $(-)$ \\
\hline 4 & $(-)$ & $(+)$ & $(+)$ & Unknown & $1 \mathrm{a}$ & 1 & 0 & $\mathrm{II}_{\mathrm{A}}$ & $(-)$ & $(-)$ \\
\hline 5 & $(-)$ & $(+)$ & $(+)$ & Well & $2 \mathrm{a}$ & 1 & 0 & $\mathrm{II}_{\mathrm{A}}$ & $(-)$ & $(-)$ \\
\hline 6 & $(+++)$ & $(-)$ & $(-)$ & Unknown & 3 & 0 & 0 & $\mathrm{II}_{\mathrm{B}}$ & $(-)$ & $(-)$ \\
\hline 7 & $(+++)$ & $(+)$ & $(+)$ & Poorly & 3 & $\mathrm{X}$ & 0 & Unknown & $(++)$ & $(+++)$ \\
\hline 8 & $(-)$ & $(+)$ & $(-)$ & Moderately & $1 b$ & 0 & 0 & $\mathrm{I}_{\mathrm{A}}$ & $(-)$ & $(+++)$ \\
\hline 9 & $(-)$ & $(-)$ & $(-)$ & Well & $1 \mathrm{a}$ & $\mathrm{X}$ & 0 & Unknown & $(++)$ & $(-)$ \\
\hline 10 & $(-)$ & $(+)$ & $(-)$ & Well & $2 \mathrm{a}$ & 1 & 0 & $\mathrm{II}_{\mathrm{A}}$ & $(-)$ & $(-)$ \\
\hline 11 & $(-)$ & $(-)$ & $(+)$ & Moderately & 4 & 2 & 0 & $\mathrm{III}_{\mathrm{B}}$ & $(-)$ & $(++)$ \\
\hline 12 & $(+)$ & $(+)$ & $(-)$ & Poorly & 3 & 0 & 0 & $\mathrm{II}_{\mathrm{B}}$ & $(-)$ & $(-)$ \\
\hline 13 & $(-)$ & $(-)$ & $(-)$ & Well & $1 b$ & 0 & 0 & $\mathrm{I}_{\mathrm{A}}$ & $(-)$ & $(-)$ \\
\hline 14 & $(-)$ & $(-)$ & $(-)$ & Moderately & $2 a$ & 0 & 0 & $\mathrm{I}_{\mathrm{B}}$ & $(-)$ & $(-)$ \\
\hline 15 & $(+)$ & $(-)$ & $(-)$ & Moderately & 3 & 0 & 0 & $\mathrm{II}_{\mathrm{B}}$ & $(-)$ & $(-)$ \\
\hline 16 & $(-)$ & $(-)$ & $(-)$ & Moderately & $2 \mathrm{a}$ & 0 & 0 & $\mathrm{I}_{\mathrm{B}}$ & $(+)$ & $(++)$ \\
\hline 17 & $(-)$ & $(+)$ & $(-)$ & Moderately & 1a & 0 & 0 & $\mathrm{I}_{\mathrm{A}}$ & $(-)$ & $(-)$ \\
\hline 18 & $(-)$ & $(-)$ & $(+)$ & Moderately & $1 b$ & 0 & 0 & $\mathrm{I}_{\mathrm{A}}$ & $(-)$ & $(-)$ \\
\hline 19 & $(-)$ & $(-)$ & $(+)$ & Moderately & $2 \mathrm{a}$ & 2 & 0 & $\mathrm{III}_{\mathrm{A}}$ & $(-)$ & $(-)$ \\
\hline 20 & $(+++)$ & $(+)$ & $(+)$ & Moderately & 3 & 1 & 0 & $\mathrm{III}_{\mathrm{A}}$ & $(-)$ & $(-)$ \\
\hline 21 & $(+)$ & $(+)$ & $(-)$ & Moderately & $2 \mathrm{a}$ & 0 & 0 & $\mathrm{I}_{\mathrm{B}}$ & $(-)$ & $(-)$ \\
\hline 22 & $(-)$ & $(-)$ & $(+)$ & Moderately & $2 b$ & 2 & 0 & $\mathrm{III}_{\mathrm{A}}$ & $(-)$ & $(-)$ \\
\hline 23 & $(+)$ & $(-)$ & $(+)$ & Moderately & $2 \mathrm{a}$ & 0 & 0 & $\mathrm{I}_{\mathrm{B}}$ & $(-)$ & $(+)$ \\
\hline 24 & $(++)$ & $(+)$ & $(+)$ & Moderately & $2 \mathrm{a}$ & 0 & 0 & $\mathrm{I}_{\mathrm{B}}$ & $(-)$ & $(-)$ \\
\hline 25 & $(++)$ & $(-)$ & $(+)$ & Moderately & $2 \mathrm{a}$ & 0 & 0 & $\mathrm{I}_{\mathrm{B}}$ & $(-)$ & $(-)$ \\
\hline 26 & $(-)$ & $(+)$ & $(+)$ & Moderately & $1 \mathrm{a}$ & 2 & X & $\mathrm{III}_{\mathrm{A}}$ & $(-)$ & $(-)$ \\
\hline 27 & $(-)$ & $(+)$ & $(+)$ & Moderately & $1 b$ & 2 & 0 & $\mathrm{III}_{\mathrm{A}}$ & $(-)$ & $(-)$ \\
\hline 28 & $(+)$ & $(+)$ & $(-)$ & Well & $2 \mathrm{a}$ & 0 & 0 & $\mathrm{I}_{\mathrm{B}}$ & $(-)$ & $(-)$ \\
\hline 29 & $(+)$ & $(+)$ & $(-)$ & Well & $2 \mathrm{a}$ & 0 & 0 & $\mathrm{I}_{\mathrm{B}}$ & $(-)$ & $(-)$ \\
\hline 30 & $(+++)$ & $(-)$ & $(-)$ & Moderately & $3 a$ & 0 & 0 & $\mathrm{II}_{\mathrm{B}}$ & $(-)$ & $(-)$ \\
\hline 31 & $(+)$ & $(-)$ & $(+)$ & Poorly & $2 \mathrm{a}$ & 1 & 0 & $\mathrm{II}_{\mathrm{A}}$ & $(-)$ & $(-)$ \\
\hline 32 & $(+++)$ & $(-)$ & $(-)$ & Well & 3 & 1 & 0 & $\mathrm{III}_{\mathrm{A}}$ & $(-)$ & $(-)$ \\
\hline
\end{tabular}

These agents are now available for lung cancer, including gefitinib and erlotinib for mutations of EGFR and crizotinib for the EML4-ALK fusion gene (32-35).

In this study, we focused on MET and EGFR as putative targets of tumor-suppressive $m i R-206$. We demonstrated that theseRTKs were directly regulated by $m i R$-206. Overexpression of MET protein in tumor tissue (relative to adjacent normal tissues) occurs in $27-77 \%$ of NSCLC and is associated with a poor prognosis (35). Also, upregulation of EGFR was reported in $40-80 \%$ of patients (36). MET signaling pathways are tightly regulated in normal cells. However, in cancer cells, activating
MET signals promote cell proliferation, invasion, metastasis and angiogenesis (37-39). Activation of MET signals causes transcriptional deregulation, genetic abnormalities and crosstalk between MET and other RTKs (37-39). Although patients with NSCLC initially benefit from EGFR targeted therapies, some patients ultimately acquire resistance to agents, leading to disease progression (8). Importantly, in patients who have acquired resistance to EGFR TKI, the MET amplification rate is approximately $20 \%(9,10)$. Therefore, inhibition of MET signaling must be targeted in this disease. Such therapeutics is in fact now available (35,37-39). In the present study, we found 
one patient with overexpression of both MET and EGFR in lung-SCC lesions. In this situation, dual inhibition treatment of MET and EGFR is necessary.

Several studies reported that MET or EGFR were directly regulated by several miRNAs, such as $m i R-1 / 206, m i R-7$ and $m i R-146 a$ in several cancer cell types (40-43). A recent study demonstrated that $m i R-27 a$ regulated both EGFR and MET in NSCLC (44). Our present data demonstrated that $m i R-206$ clearly inhibited both MET and EGFR expression and their associated signaling in cancer cells. Dual inhibition of tyrosine kinases by tumor-suppressive $m i R-27 a$ and $m i R-206$ is a very attractive treatment option for the treatment of lung-SCC lesions.

In conclusion, $m i R-206$ was significantly downregulated in lung-SCC clinical specimens. It appeared to function as a tumor suppressor through regulation of oncogenic RTKs (MET and EGFR) and their associated downstream signaling. Elucidation of the cancer pathways and target genes regulated by tumor-suppressive miR-206 should provide new approaches and potential therapeutic targets in the treatment of lung-SCC.

\section{Acknowledgements}

We thank Ms. Mutsumi Miyazaki for her excellent laboratory assistance.

\section{References}

1. Jemal A, Bray F, Center MM, Ferlay J, Ward E and Forman D.: Global cancer statistics. CA Cancer J Clin 61: 69-90, 2011.

2. Travis WD: Pathology of lung cancer. Clin Chest Med 32: 669-692, 2011.

3. Reck M,Heigener DF, Mok T, Soria JC and Rabe KF: Management of non-small-cell lung cancer: recent developments. Lancet 382: 709-719, 2013.

4. Gschwind A, Fischer OM and Ullrich A: The discovery of receptor tyrosine kinases: targets for cancer therapy. Nat Rev Cancer 4: 361-370, 2004.

5. Cadena DL and Gill GN: Receptor tyrosine kinases. FASEB J 6: 2332-2337, 1992.

6. Engelman JA and Cantley LC: The role of the ErbB family members in non-small cell lung cancers sensitive to epidermal growth factor receptor kinase inhibitors. Clin Cancer Res 12 S4372-S4376, 2006.

7. Gherardi E, Birchmeier W, Birchmeier C and Vande Woude G: Targeting MET in cancer: rationale and progress. Nat Rev Cancer 12: 89-103, 2012.

8. Sacher AG, Janne PA and Oxnard GR: Management of acquired resistance to epidermal growth factor receptor kinase inhibitors in patients with advanced non-small cell lung cancer. Cancer 120: 2289-2298, 2014

9. Engelman JA, Zejnullahu K, Mitsudomi T, et al: MET amplification leads to gefitinib resistance in lung cancer by activating ERBB3 signaling. Science 316: 1039-1043, 2007.

10. Bean J, Brennan C, Shih JY, et al: MET amplification occurs with or without T790M mutations in EGFR mutant lung tumors with acquired resistance to gefitinib or erlotinib. Proc Natl Acad Sci USA 104: 20932-20937, 2007.

11. Bartel DP: MicroRNAs: genomics, biogenesis, mechanism, and function. Cell 116: 281-297, 2004.

12. Hobert O: Gene regulation by transcription factors andmicroRNAs. Science 319: 1785-1786, 2008.

13. Iorio MV and Croce CM: MicroRNAs in cancer: small molecules with a huge impact. J Clin Oncol 27: 5848-5856, 2009.

14. Rolfo C, Fanale D, Hong DS, et al: Impact of microRNAs in resistance to chemotherapy and novel targeted agents in non-small cell lung cancer. Curr Pharm Biotechnol 15: 475-485, 2014.

15. Filipowicz W, Bhattacharyya SN and Sonenberg N: Mechanisms of post-transcriptional regulation by microRNAs: are the answers in sight? Nat Rev Genet 9: 102-114, 2008.
16. Friedman JM and Jones PA: MicroRNAs: critical mediators of differentiation, development and disease. Swiss Med Wkly. 139: 466-472, 2009.

17. Moriya Y, Nohata N, Kinoshita T, et al: Tumor suppressive microRNA-133a regulates novel molecular networks in lung squamous cell carcinoma. J Hum Genet 57: 38-45, 2012.

18. Goldstraw P, Crowley J, Chansky K, et al: The IASLC Lung Cancer Staging Project: proposals for the revision of the TNM stage groupings in the forthcoming (seventh) edition of the TNM Classification of malignant tumours. J Thorac Oncol 2: 706-714, 2007.

19. Kojima S, Chiyomaru T, Kawakami K, et al: Tumour suppressors miR-1 and miR-133a target the oncogenic function of purine nucleoside phosphorylase (PNP) in prostate cancer. Br J Cancer 106: 405-413, 2012.

20. Nohata N, Hanazawa T, Kinoshita T, et al: Tumour-suppressive microRNA-874 contributes to cell proliferation through targeting of histone deacetylase 1 in head and neck squamous cell carcinoma. Br J Cancer 108: 1648-1658, 2013.

21. Kinoshita T, Nohata N, Hnasawa T, et al: Tumour-suppressive microRNA-29s inhibit cancer cell migration and invasion by targeting laminin-integrin signalling in head and neck squamous cell carcinoma. Br J Cancer 109: 2636-2645, 2013.

22. Yoshino H, Chiyomaru T, Enokida H, et al: The tumoursuppressive function of miR-1 and miR-133a targeting TAGLN2 in bladder cancer. Br J Cancer 104: 808-818, 2011.

23. Koeppen $\mathrm{H}, \mathrm{Yu} \mathrm{W}, \mathrm{Zha} \mathrm{J}$, et al: Biomarker analyses from a placebo-controlled phase II study evaluating erlotinib \pm onartuzumab in advanced non-small cell lung cancer: MET expression levels are predictive of patient benefit. Clin Cancer Res 20: 44884498, 2014.

24. Itesako T, Seki N, Yoshino H, et al: The microRNA expression signature of bladder cancer by deep sequencing: the functional significance of the miR-195/497 cluster. PLoS One 9: e84311, 2014.

25. Hidaka H, Seki N, Yoshino H, et al: Tumor suppressive microRNA-1285 regulates novel molecular targets: aberrant expression and functional significance in renal cell carcinoma. Oncotarget 3: 44-57, 2012.

26. Nohata N, Hanazawa T, Enokida $H$ and Seki N: microRNA-1/133a and microRNA-206/133b clusters: dysregulation and functional roles in human cancers. Oncotarget 3: 9-21, 2012.

27. Georgantas R, Streicher K, Greenless L, et al: MicroRNA-206 induces G1 arrest in melanoma by inhibition of CDK4 and Cyclin D. Pigment Cell Melanoma Res 27: 275-286, 2014.

28. Missiaglia E, Shepherd C.J, Patel S, et al: MicroRNA-206 expression levels correlate with clinical behaviour of rhabdomyosarcomas. Br J Cancer 102: 1769-1777, 2010.

29. Yan D, Dong Xda E, Chen X, et al: MicroRNA-1/206 targets c-Met and inhibits rhabdomyosarcoma development. J Biol Chem 284: 29596-29604, 2009.

30. Chen X, Yan Q, Li S, et al: Expression of the tumor suppressor miR-206 is associated with cellular proliferative inhibition and impairs invasion in ERalpha-positive endometrioid adenocarcinoma. Cancer Lett 314: 41-53, 2012.

31. Kondo N, Toyama T, Sugiura H, et al: miR-206 expression is down-regulated in estrogen receptor alpha-positive human breast cancer. Cancer Res 68: 5004-5008, 2008.

32. Maemondo M, Inoue A, Kobayashi K, et al: Gefitinib or chemotherapy for non-small-cell lung cancer with mutated EGFR. N Engl J Med 362: 2380-2388, 2010.

33. Zhou C, Wu YL, Chen G, et al: Erlotinib versus chemotherapy as first-line treatment for patients with advanced EGFR mutationpositive non-small-cell lung cancer (OPTIMAL, CTONG-0802): a multicentre, open-label, randomised, phase 3 study. Lancet Oncol 12: 735-742, 2011.

34. Shaw AT, Yeap BY, Solomon BJ, et al: Effect of crizotinib on overall survival in patients with advanced non-small-cell lung cancer harbouring ALK gene rearrangement: a retrospective analysis. Lancet Oncol 12: 1004-1012, 2011.

35. Scagliotti GV, Novello $S$ and von Pawel J: The emerging role of MET/HGF inhibitors in oncology. Cancer Treat Rev 39: 793-801, 2013.

36. Gately K, Forde L, Cuffe S, et al: High coexpression of both EGFR and IGF1R correlates with poor patient prognosis in resected non-small-cell lung cancer. Clin Lung Cancer 15: 58-66, 2014.

37. Maroun CR and Rowlands T: The Met receptor tyrosine kinase: a key player in oncogenesis and drug resistance. Pharmacol Ther 142: 316-338, 2014. 
38. Sadiq AA and Salgia R: MET as a possible target for non-smallcell lung cancer. J Clin Oncol 31: 1089-1096, 2013.

39. Cipriani NA, Abidoye OO, Vokes E and Salgia R: MET as a target for treatment of chest tumors. Lung Cancer 63: 169-179, 2009.

40. Nasser MW, Datta J, Nuovo G, et al: Down-regulation of micro-RNA-1 (miR-1)in lung cancer. Suppression of tumorigenic property of lung cancer cells and their sensitization to doxorubicin-induced apoptosis by miR-1. J Biol Chem 283: 33394-33405, 2008.

41. Taulli R, Bersani F, Foglizzo V, et al: The muscle-specific microRNA miR-206 blocks human rhabdomyosarcoma growth in xenotransplanted mice by promoting myogenic differentiation. J Clin Invest 119: 2366-2378, 2009.
42. Kefas B, Godlewski J, Comeau L, et al: microRNA-7 inhibits the epidermal growth factor receptor and the Akt pathway and is down-regulated in glioblastoma. Cancer Res 68: 3566-3572, 2008.

43. Li Y, Vandenboom TG II, Wang Z, et al: miR-146a suppresses invasion of pancreatic cancer cells. Cancer Res 70: 1486-1495, 2010.

44. Acunzo M, Romano G, Palmieri D, et al: Cross-talk between MET and EGFR in non-small cell lung cancer involves miR-27a and Sprouty2. Proc Natl Acad Sci USA 110: 8573-8578, 2013. 